informacji poświęcono najwięcej miejsca, a artykuły opublikowane są m.in. w postaci multimedialnej (CD ROM ISBN 80-7184-153-6) w czasopismach naukowych oraz innych opracowaniach i periodykach zagranicznych (USA, Chiny, Belgia, Holandia, Czechy), w publikacjach PAN, UW, PTG, TIP, Instytutu Badań Systemowych PAN, PTI, PTE oraz pracach różnych ośrodków akademickich (Gdańsk, Toruń, Wrocław, Szczecin, Poznań, Warszawa, Opole).

Antoni Korowicki

\section{Geografia turyzmu w Szkole Glównej Handlowej w Warszawie}

W Katedrze Geografii Ekonomicznej Szkoły Głównej Handlowej (SGH) zagadnienia z zakresu turystyki jako pierwszy podjął prof. Stanisław Berezowski, nawiązując do dorobku swego promotora prof. Stanisława Leszczyckiego. Następnie problematyką turystyki zajmował się prof. Kazimierz Kuciński. Kontynuatorem prac prof. S. Berezowskiego i prof. K. Kucińskiego jest obecnie dr Marcin Molenda, zajmujący się rolą turystyki w rozwoju lokalnym oraz wykorzystaniem kapitału ludzkiego w turystyce. Doktor Molenda jest autorem licznych publikacji z zakresu geografii turystyki, w tym rozdziału o turystyce w Geografii ekonomicznej Unii Europejskiej. Prowadzi w SGH wykłady z zakresu geografii turystyki oraz seminaria licencjackie i magisterskie dotyczące regionalizacji turystycznej, a także wpływu turystyki na gospodarkę różnych krajów.

Od 1956 r. w SGH istnieje również Katedra Turystyki, która powstała jako Zakład Prawnych i Ekonomicznych Zagadnień Turystyki w Katedrze Prawa Międzynarodowego na Wydziale Handlu Zagranicznego. Pierwszym kierownikiem Zakładu (1956-1975) był prof. Kazimierz Libera, a następnie (1975-1994) doc. Olaf Rogalewski. Od 1994 r. Katedrą kieruje prof. Stanisław Wodejko.

W SGH funkcjonuje na studiach magisterskich kierunek „turystyka i rekreacja” ze specjalnością ,turystyka międzynarodowa” oraz ,,biznes turystyczny". Prowadzone są też studia podyplomowe kształcące menadżerów turystyki.
(CD ROM: ISBN 80-7184-153-6), in academic journals and in international publications and periodicals (in the USA, China, Belgium, the Netherlands and the Czech Republic), in the publications of such Polish institutions as the Polish Academy of Science, the University of Warsaw, the Polish Geographical Society, TIP, the Institute of Systematic Studies of the Polish Academy of Science, the Polish Information Processing Society, the Polish Economic Society and in papers published by various academic centres (Gdańsk, Torun, Wroclaw, Szczecin, Poznań, Warszawa and Opole).

Antoni Korowicki

\section{Geography of tourism at the Warsaw School of Economics}

In the Department of Economic Geography at the Warsaw School of Economics (WSE), research in tourism issues was started by Prof. Stanisław Bereżowski linked to the work of his former supervisor Prof. Stanisław Leszczycki, which was then continued by Prof. Kazimierz Kuciński. The projects initiated by Prof. Bereżowski and Prof. Kuciński are at present continued by Dr Marcin Molenda whose academic focus is on the role of tourism in local development and the use of human resources in tourism. He is the author of numerous publications on tourism geography including a chapter on tourism in 'Economic Geography in the European Union'. In WSE he lectures on tourism geography and has Licencjat and MA seminars on tourist regionalization and the influence of tourism on the economy of different countries.

Since 1956 WSE has also had a Department of Tourism which started as a research unit on the Legal and Economic Issues of Tourism, in the Department of International Law and Foreign Trade. The unit was first headed by Prof. Kazimierz Libera (1956-1975), then by Prof. Olaf Rogalewski (1975-1994), and since 1994 by Prof. Stanisław Wodejko.

Among its MA programmes, WSE offers a Master's degree in Tourism and Recreation with two specializations: International Tourism and Tourist Business. There are also postgraduate programmes in tourism management.

Marcin Molenda 